\title{
Politico-Economic Conditions of Ilkhanid Coins from Different Mint Houses by PIXE
}

\author{
Javad Neyetani ${ }^{1}$, Amirhossein Salehi ${ }^{1{ }^{* *}, \text { Seyed Mehdi Mousavi }}{ }^{1}$, Mahdi Hajivaliei ${ }^{2}$, \\ Ali Reza Hejabri Noubari ${ }^{1}$

\begin{abstract}
${ }^{1}$ Department of Archaeology Faculty of Humanities, Tarbiat Modares University, Jalal Al-Ahmad Highway, Nasr Bridge, Tehran, Iran ${ }^{2}$ Physics Department, Bu-Ali Sina University, Mahdiyeh St., Hamedan, Iran

*Corresponding Author: amirhossein.salehi@modares.ac.ir
\end{abstract}

Copyright $(2014$ Horizon Research Publishing All rights reserved.

\begin{abstract}
It has been proved that the basic changes in post-Islam coin minting have been occurred in Ilkhanid era; therefore a survey on the time coins may help us understand the changes and econopolitical situation of the era. In this research, we have applied the non-destructive PIXE method to test 32 Ilkhanid coins belonging to various rulers. The highest and the lowest silver percent's in Damghan were related to Ghazan, and Tegudar and Arghun, respectively. Regarding the conditions of the coins in Arghun era, we may conclude that he had been engaged in the area's conflicts. Most of the coins have mostly close roots, except for two cases.
\end{abstract}

Keywords Ilkhanid, PIXE, Mint House, Silver

\section{Introduction}

Analysis of the silver coins in mints helps us know the economic and political situation of various kings and dynasties. Data about the coins' composition help the archeologists and are of great importance for historians [1]. The PIXE method may be useful in spectrometry of many chemical elements [2].Even though other spectrograph tools like XRF could provide more information of the elements in metals being analyzed and are cheaper, accuracy of the spectrograph used in this study is significantly higher and has less limitations[3, 4].

Karry and Emeleus; and Gordus studied a great number of silver coins of various eras and revealed that gold impurity level in silver coins has been below 1\%. This level may show that various mines and different production centers were used[5, 6, 7]. Meyers' works on silver objects strongly suggested that iridium concentration can be used in provenance studies in neutron activation analyses data [8]. Also, he proved that the elements applied in silver objects in Iran and other regions help us to understand the silver production in various times. Systematic changes in average gold content of silver objects as a function of time and place provide us with a general scheme of silver production technology. The silver extraction technology is divided into three periods: at first silver ore was used in this regard. Then at the late 3rd millennium B.C the technology of Cerussite mines application was used in the form of oxidized lead ores. The last period in Iran begins from the first millennium A.D. when silver was extracted from Galena mines in the form of lead sulfide ores [9].

The Islamic era has been studied in different places including coins in Abbasid eras using XRF method and in Mamluk and Ayyubid dynasties using PIXE method [10,11].

The recent researches concerning the Islamic era's rulers in Iran, along with studies on ancient mines [12] would solve many problems in this regard. Studying the ores and comparing them with metal objects built from them could provide information on metallurgy levels and communications in the past[13]. The researches include studies on Iranian and Roman coins of the Saljuqid dynasty conducted using PIXE [14] and study on king Ghazan silver coins by PIXE [15]. The silver, lead and gold percent's used in the coins are considered as indices for economic situation technical knowledge and mines variety, respectively.

\section{Instruments}

The analysis was carried out by using a $2 \mathrm{MeV}$ proton beam from Atomic Energy Organization of Iran (AEOI) (fig 1), to bombarded the coins. The current of beam was 2-3 nA. The multipurpose scattering chamber with a vacuum of about $10^{-5}$ Torr was used.

The emitted characteristic X-rays from sample were detected using an ORTEC Si (Li) detector with $170 \mathrm{eV}$ measured FWHM energy resolution at $5.9 \mathrm{keV}$ (fig 2).

The raw data have been analyzed with the GUPIX package _Guelph PIXE software package [16]_ major elements are those contributing $10 \%$ to overall composition, minor elements 0.1 to $10 \%$ and trace elements less than $0.1 \%$, down to detection limits. The test measurement for PIXE was done by 1 Euro coin (table1) which earlier also reported 
by Roumie et al.[17].

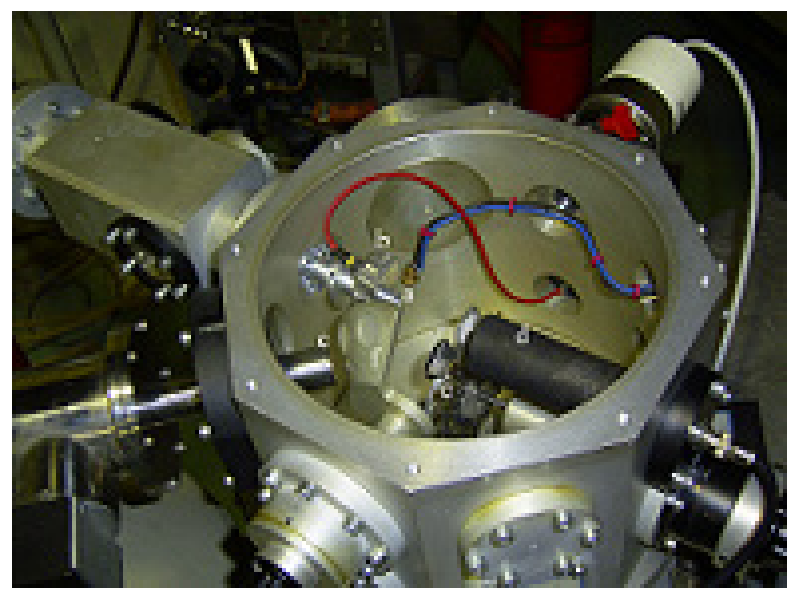

Figure 1. Target chamber

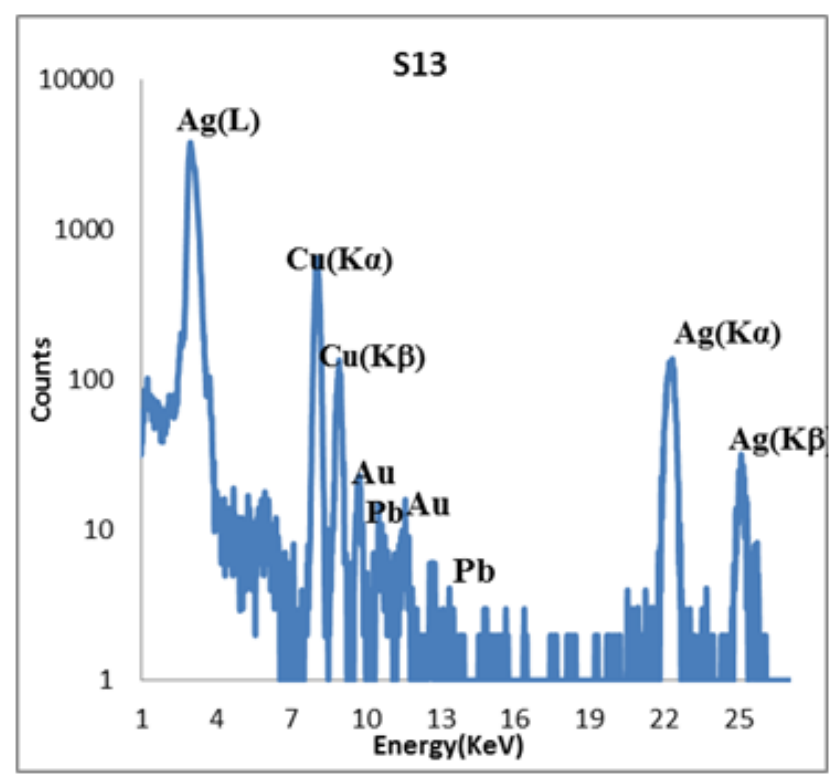

Figure 2. Typical PIXE spectrum of coin No. 31

\section{Preparation of Samples}

We have selected 32 silver coins of Ilkhanid from different mint house (fig.3). Samples were collected from national private collection. The coins were cleaned and for better result were submitted to conservation office before analysis. The coins were immersed in an Ethanol for two hours and after cleaning by acetone, the coins were washed with distilled water. Due to the clearness of the Persian descript on the Ilkhanid coins, no need for any more cataloging to the silver coins.

\section{History of Ilkhanid}

The first confrontation between Persian and Mongols took place in 1219 with Jinghiz Khan Assault of Persia. The next assault was in 1256 leading in the establishment of a Mongolian government [18]. With ties to the great Khan, Only during the time of Ghazan (1295-304) the name of great Khan was left out from the Ilkhanid coins [19]. After the Holako a number of Ilkhanid rulers came to power with time of them being sons of Holako, i.e., Abagha (1265), Tagoodar (1281) and Arghoon (1284) [18]. The Ilkhanid empire in Iran met its end in 1340 by abdication OF Jahan Teymoor. The economic area of the Mongolian like itssimilar to social is divided in to three periods. The invasion of Jinghiz khan and continues till Holako"s ruling in 654. The most prominent time belong to the next period culminating in Ghazan's reforms [20]. The Ilkhanid silver coins lacked standard before the beginning of Ghazan's ruling and only during the role of this Ilkhan and his minister, Rashidodin, standardization of the coins in terms of weight, purity, and type took place [19]. The coins of Ghazan and rulers after him, i.e., Oljaito and Abusaid, are plentiful and of high quality [21] but this only lasts till Abusaid's death. In the third period Ilkhans downward and then deterioration continue after the death of the last Ilkhan [20].

Obverse

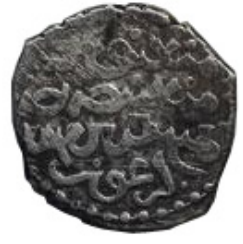

7

Reverse

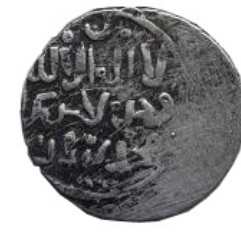

7

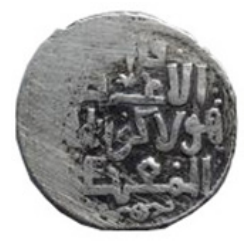

5

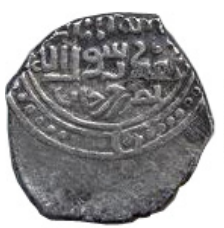

5

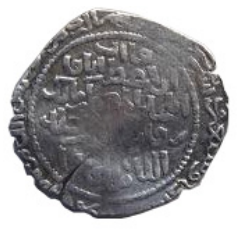

14

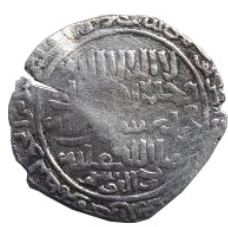

14
Figure 3. Both sides of sample of silver Ilkhanid coins analyzed

\section{Discussion and Data Analysis}

Analysis of 32 Ilkhanid era's coins (tables 1 and 2) revealed that the highest $(98.26 \%)$ and lowest $(53.36 \%)$ level of Ag to Arghun, respectively, and mint houses of Tabriz, Esfarayen and Musel had the highest percent of silver(fig 4).

Any silver coin for Muslims was a dirham [22]Ilkhanid dynasty's silver coins lacked standards before Ghazan era, but he and his vizier, Rashideddin began standardization of weight, purity and type [19]. Ghazan and his successors, Uljaito and Abusaid produced high quality coins[21]; this was also confirmed in our analyses, Data suggests that all Ghazan coins, except one (No. 3), had high percentage of silver in them, over $91 \%$.. 
Table 1. Percentage of chemical elements in analyzed coins

\begin{tabular}{|c|c|c|c|c|c|c|c|c|}
\hline Sample & $\mathrm{Cr}$ & $\mathrm{Fe}$ & $\mathrm{Ni}$ & $\mathrm{Cu}$ & $\mathrm{Zn}$ & $\mathrm{Ag}$ & $\mathrm{Au}$ & $\mathrm{Pb}$ \\
\hline Euro & - & 0.09 & 24.81 & 74.59 & - & - & - & - \\
\hline 1 & - & - & - & 4.89 & - & 93.11 & 0.90 & 1.10 \\
\hline 2 & - & 0.05 & - & 3.97 & - & 93.80 & 1.03 & 1.15 \\
\hline 3 & - & - & - & 16.10 & - & 81.84 & 1.05 & 1.01 \\
\hline 4 & - & - & - & 15.98 & - & 82.36 & 0.82 & 0.84 \\
\hline 5 & - & - & - & 12 & - & 86.05 & 0.85 & 1.10 \\
\hline 6 & 0.09 & 0.20 & - & 3.06 & 0.13 & 93.62 & 0.80 & 2.10 \\
\hline 7 & - & 0.04 & - & 9.26 & - & 89.00 & 0.87 & 0.83 \\
\hline 8 & - & - & - & 9.75 & - & 89.14 & 0.45 & 0.66 \\
\hline 9 & - & - & - & 5.45 & - & 90.91 & 0.69 & 2.95 \\
\hline 10 & - & - & - & 26.72 & - & 71.34 & 0.84 & 1.10 \\
\hline 11 & - & - & - & 14.04 & - & 84.13 & 0.90 & 0.93 \\
\hline 12 & - & 0.05 & - & 5.16 & - & 93.26 & 0.79 & 0.74 \\
\hline 13 & - & 0.05 & - & 7.20 & - & 89.00 & 0.80 & 2.05 \\
\hline 14 & - & - & - & 6.70 & - & 92.00 & 0.83 & 0.47 \\
\hline 15 & - & 0.05 & - & 16.87 & - & 81.00 & 0.75 & 1.33 \\
\hline 16 & - & - & - & 6.00 & - & 92.61 & 0.39 & 1.00 \\
\hline 17 & - & 0.04 & - & 6.24 & - & 92.28 & 0.67 & 0.77 \\
\hline 18 & - & 0.07 & - & 32.57 & - & 65.68 & 0.65 & 1.03 \\
\hline 19 & - & - & - & 6.52 & - & 91.21 & 1.45 & 0.82 \\
\hline 20 & - & - & - & 1.24 & - & 98.26 & 0.19 & 0.31 \\
\hline 21 & - & - & - & 2.41 & - & 95.39 & 1.10 & 1.10 \\
\hline 22 & - & - & - & 5.10 & - & 93.20 & 0.94 & 0.76 \\
\hline 23 & - & - & - & 9.05 & - & 89.35 & 1.17 & 0.43 \\
\hline 24 & - & - & - & 8.97 & - & 89.48 & 0.68 & 0.87 \\
\hline 25 & - & - & - & 2.61 & - & 95.00 & 1.39 & 1.00 \\
\hline 26 & - & - & - & 4.47 & - & 91.70 & 1.01 & 2.82 \\
\hline 27 & - & - & - & 40.85 & 3.85 & 53.36 & 1.08 & 0.86 \\
\hline 28 & - & - & - & 9.60 & - & 88.54 & 1.07 & 0.79 \\
\hline 29 & - & - & - & 2.83 & - & 95.73 & 0.73 & 0.71 \\
\hline 30 & - & 0.03 & - & 4.68 & - & 93.00 & 1.20 & 1.12 \\
\hline 31 & - & - & - & 6.38 & - & 92.27 & 0.92 & 0.43 \\
\hline 32 & - & - & - & 5.22 & - & 93.54 & 0.98 & 0.26 \\
\hline
\end{tabular}


Table 2. Characteristics of the thirty two analyzed silver coins

\begin{tabular}{|c|c|c|c|}
\hline Sample & Point A & Town & Weight \\
\hline 1 & Arghun & Yazd & 2.82 \\
\hline 2 & & & 2.94 \\
\hline 3 & Ghazan & & 2.54 \\
\hline 4 & Arghun & Bazar Ordu & 2.24 \\
\hline 5 & Arghun & Jurjan & 2.86 \\
\hline 6 & Ghazan & & 2.10 \\
\hline 7 & Hulagu & & 2.04 \\
\hline 8 & Arghun & Astarabad & 3.41 \\
\hline 9 & Arghun & Damghan & 3.11 \\
\hline 10 & Arghun & Astarabad & 2.90 \\
\hline 11 & Arghun & Damghan & 2.54 \\
\hline 12 & Arghun & Damghan & 2.30 \\
\hline 13 & Arghun & Yazd(yosef shah) & 2.51 \\
\hline 14 & Abaqa & & 2.36 \\
\hline 15 & Arghun & & 2.34 \\
\hline 16 & Abaqa & Muscel & 2.54 \\
\hline 17 & Hulagu & & 2.01 \\
\hline 18 & Ahmad & & 2.34 \\
\hline 19 & Ghazan & & 2.62 \\
\hline 20 & Arghun & & 2.10 \\
\hline 21 & Ghazan & Tabriz & 2.20 \\
\hline 22 & Arghun & & 2.94 \\
\hline 23 & Arghun & & 2.51 \\
\hline 24 & Arghun & Damghan & 2.51 \\
\hline 25 & Arghun & Damghan & 2.86 \\
\hline 26 & Ghazan & & 2.63 \\
\hline 27 & Arghun & Damghan & 2.14 \\
\hline 28 & Arghun & Damghan & 2.74 \\
\hline 29 & Arghun & Damghan & 1.85 \\
\hline 30 & Ghazan & & 3.24 \\
\hline 31 & Arghun & Tabriz & 2.42 \\
\hline 32 & Ghazan & Isfarayin & 2.31 \\
\hline
\end{tabular}

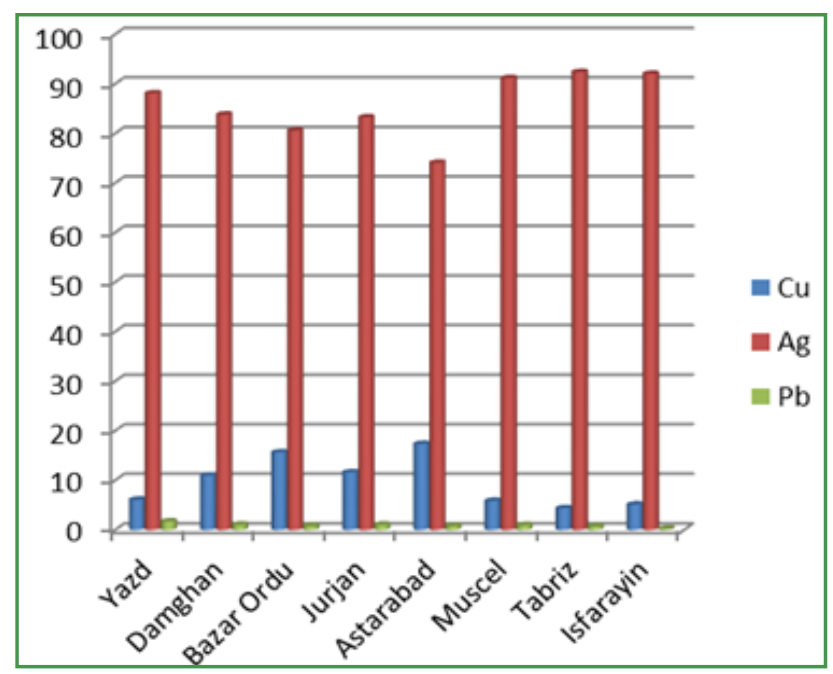

Figure 4. Variation of $\mathrm{Cu}, \mathrm{Ag}, \mathrm{Pb}$ in each Mint house 
Copper changes (fig 5) show economic and political changes, and war situations. Adding copper to silver coins may not be assumed as a technique for hardening [23]. We don't know the reasons for adding bronze alloy instead of copper in Arghun coins as well as minting silver coins with very low percent (54\%). However, Arghun faced a war around Damghan. In order to pay the war expenses, they started to mint silver coins with high percentage of cupper.

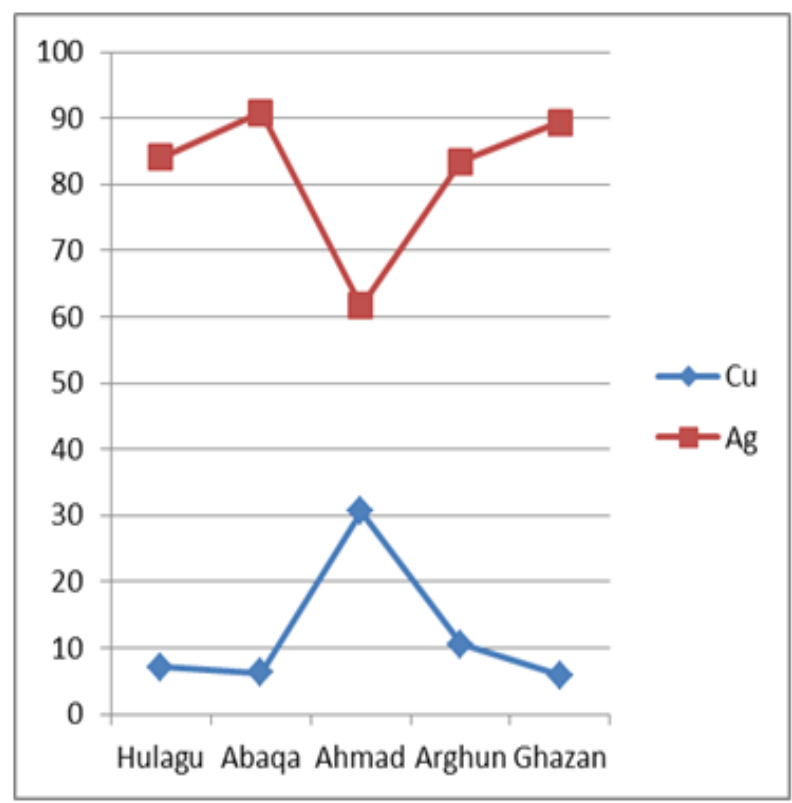

Figure 5. $\mathrm{Ag}$ and $\mathrm{Cu}$ percentage in the analyses Ilkhanid silver coins.

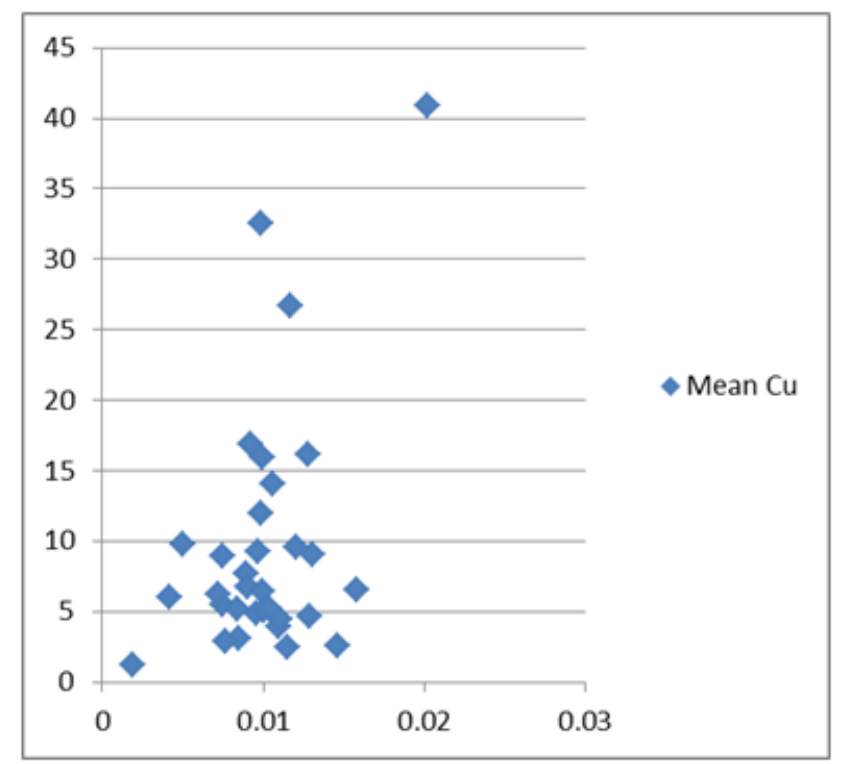

Figure 6. Plot o the ratios of gold to silver and copper

Lead is a technical element in producing silver coins [23]The trace concentration of $\mathrm{Pb}$ indicates that the process used to refine silver was great.[4].

Hich are related to the silver ores and metallurgy, we have also. Arghun coins in Yazd have the highest amount of lead which is a sign of silver extraction from the lead - zincsilver mines with a high lead percent. Yazd possessed very insufficient silver extraction technology relative to other mints of the Ilkhanid rulers, or Yazd's artisans lacked the required skill and precision. Considering the role of gold in recognition of various silver mines, it is cleared that the coins numbers 20 and 27 have different roots to those of other coins (fig 6).

\section{Conclusion}

The Ilkhanid silver coins have experienced many events just as their history. The show the maximum and minimum silver amounts in Ahmad Takudar and Arghun's coins, respectively. So, we may conclude that the Ilkhanid rulers reduced the silver of the coins when they were under pressure. Such events occurred specifically in Arghun's era around Damghan. Also, lack of skill is apparent in silver extraction from silver - zinc - lead mines in Yazd during his govern ship.

\section{Acknowledgments}

We are thankful from Mr. Safer which has provide these silver coin from private collection we also thanks Dr. Oliaee who has down spectrograph in vandograph in atomic energy.

\section{REFERENCES}

[1] Gurra, M. F. (1998) Analysis of Archaeological Metals. The place of XRF and PIXE in the determination of Technology and Provenance, X-Ray Spectrom, Vol. 27, 73-80.

[2] Hall, E. T.; Schweizer, F. and Toller, P. A. (1973) X-Ray Fluorescence Analysis of Museum object: A new instrument, Archaeometry, vol.15, No 1, 53-78.

[3] G. Weber, J. Guillaume, D. Strivay, H. P. Garnir, A. Marchal. and L. Martinot(2000) Is the External beam PIXE method suitable for determining ancient silver fineness? Nuclear Instrument and Methods on Physics Research Vol 161-163 (2000) 724-729.

[4] B.B Tripathy, TR Rautray, AC Rautray. andV. Vijayan(2010) Elemental analysis of silver coins by PIXE technique, Applied Radiation andisotopes, Vol. 68, 454-458

[5] CM. Kraay and V.M. Emeleus, "The Composition of Greek SilverCoins: Analysis by Neutron Activation," Oxford UniversityPress, Oxford, England, 1962.

[6] Gordus, A. A. 1995: Neutron Activation Analysis of MicrogramSamples of Sasanian Coins and Metallic Art, Material Issues in Art and Archaeology IV. In: Materials Research Society Symposium Proceedings,Vol. 352 Pittsburgh, U.S.A, 613

[7] Gordus, A. A. 1972: Neutron Activation Analysis of coins and coins streaks.In: Hall, E, T., Metcalf, D. M. (Eds.): Methods of chemicaland metallurgical of Ancient coinage, RoyalNumismatic Society spec,publ. 8, 127-148 
[8] Meyers, P. (1976) Interpretation of Neutron Activation Analysis Data of Ancient Silver. In: Conference of Archaeometry and Archaeological Prospecting, Edinburg, $\mathrm{UK}, 1-20$.

[9] Meyers, P. (2003) Production of Silver in Antiquity: ore types Identification based upon Elemental Composition of Ancient Silver Artifacts. In: Patterns and process. Maryland, USA(Ed), Zelset, L. V 271-288.

[10] Al-Kofahi, M. M. Al-Tarawneh, K. F. and Shobaki, J. M. (1997), Analysis of Abbasid dirhams using XRF techniques, X-Ray Spectrom, Vol. $26,10-14$

[11] Al-Kofahi, M. M. and Al-Tarawneh, K. F. (2000) Analysis of Ayyubid and Mamluk Dirhams, Using X-Ray Fluorescence Spectrometry, X-Ray Spectrom, Vol. 29, 39-47.

[12] Momenzadeh, M. (2004) Metallic Minerl Resources of Iran, Mind in Ancient Times. A brief review, Persiens antike pracht .In katalog der ausstellung des deutschen bergbau, museums bochum, 8-2.

[13] Lioudmila, K.(2004), Far_Eastern Bronzes: Composition and Production Technique as a Mode of Reconstruction of Cultural Contacts, 34Th International Symposium on Archaeometry, ABSTRACTS, Zaragoza (Spain).

[14] Masjedi, P.; Khademi, F.; Hajivaliei, M.; Mosavi Kouhpar, S. M. and Neystani, j. (2013) Elemental analysis of silver coins of Seljuk of Rome by PIXE: A Case Study. Mediterranean journal of archaeology and archaeometry fourt coming, In Press.

[15] Masjedi Khak, P.; Khazaei Kouhpar, M.; Hajivaliei, M. and Khademi, F. (2013).ELEMENTAL ANALYSES ON
ILKHANID PERIODCOINS BY PIXE: A CASE STUDY ONKING GHAZAN SILVER COINS, Mediterranean Archaeology and Archaeometry, Vol. 13, No 2, pp.xxxxx.

[16] Maxwell, J. A.; Teesdale, W. J. and Campbell, J. L. (1995) The Guelph PIXE software package II. Nucl. Instr. and Meth. B95, 407.

[17] Roumie, M. Nsouli, B. Chalhoub, G. Hamdan, M. (2010) Quality control of coins mint using PIXE and RBS analysis, Nuclear Inst. and Methods in Physics Research, B 268, 1916-1919.

[18] Boyle, J. A. (1968) Dynastic and Political History of the Ilkhans. In: The Cambridge History of Iran (In Eight Volumes, Volume 5, The Saljuq and Mongol Periods), J. A. Boyle, Cambrige, At the University Press.

[19] Blair, S. (1983) The Coins of the Later Ilkhanids: A Typological Analysis. Journal of the Economic and Social History of the Orient, vol. 26, No 3, 295-317.

[20] Petrushevsky, J. P. (1968) The Socio-Economic Condition of Iran Under the Ilkhans. In: The Cambridge History of Iran (In Eight Volumes, Volume 5, The Saljuq and Mongol Periods), J. A. Boyle, Cambrige, At the University Press.

[21] Masson Smith, Jr., (1969) The Silver Currency of Mongol Iran. Journal of the Economic and Social History of the Orient $12,16-41$

[22] Gignoux, P. And Bates,M. (1995) Dirham, Encyclopaedia Iranica, Vol. VII, Fasc.4, pp. 424-428.

[23] Hughes, M. .J., Hall, J. A. (1979) X-ray Fluorescence Analysis of late Roman and Sasanian Silver plate, Journal of Archaeological Science, vol. 6, No 4, 321-344. 